elsewhere regions will need to consider how they can persuade consultants that some SHO and registrar posts should be earmarked for part time trainees and that such training is credible; and the DHSS needs to look again at the provisions of $\operatorname{PM}(79) 3$ for levels below senior registrar in the light of the current intake of women into our medical schools.

T J BAYLEY

Mersey Regional Council for

Postgraduate Medical Education,

Liverpool L69 3BX

\section{Manpower discussions}

E M E RAMSAY

SIR,-The president of the Hospital Consultants and Specialists Association states (18 January, $p$ 206) that his association "was very surprised to read the evidence of the Short select committee given by the spokesmen for the medical profession, including the consultant representative on the BMA delegation, and felt obliged to conduct a survey to find out if there had been a change of attitude to the hospital staffing structure." As the "consultant representative" referred to above, I should like to put the record straight.

In 1982 the Central Committee for Hospital Medical Services supported the concept of a controlled expansion of consultants in general surgery, general medicine, and obstetrics and gynaecology; a reduction in the number of UK graduate registrars in these specialties; and the introduction of an overseas doctors training scheme. These proposals were put to the consultant body at large, and $85 \%$ of the many respondents supported these proposals. This information was included in the select committee's minutes of evidence for Wednesday 27 March 1985 , to which the president of the HCSA referred in his letter. Indeed, it states quite clearly in those minutes ( $\mathrm{p} 6$, paragraph 16) that "CCHMS did not support the Social Services Committee's general notion of a consultant provided service."

In oral evidence I used the phrase "consultant based," and from the subsequent paragraphs it is clear that I was using the phrase to describe the proposals that had been accepted by the profession in 1982. This includes an adequate number of junior doctors to provide safe on call cover for the acute specialties. The need for such cover was acknowledged by members of the select committee and the junior doctor representative on the BMA delegation. Thus the phrases "consultant provided" and "consultant based" appeared in the minutes of evidence with supporting comments that made their meaning clear. The HCSA, however, then decided to conduct a survey, to which its president referred in his letter, and in which the terms "consultant led" and "consultant based" were used. This last phrase was for some reason used in the survey to imply a service with little or no junior support for consultants.

The reason that on 14 December CCHMS defined the phrases that had been used in the profession's evidence to the select committee was to correct the confusion that was being stimulated by the misleading terms used by HCSA in its survey.

A P J Ross

$$
\text { Central Committee for Hospital Medical Services, }
$$

BMA House,

London WCIH 9JP

\section{Breaches of confidence}

SIR,-When I read Dr Dora Black's Personal View (14 December, $p$ 1718) I could not believe what $I$ was reading. As an anaesthetist I am not conver- sant with the pros and cons of an open access system for patient records in general practice, but it would seem on the basis of common sense that the resultant destruction of interprofessional trust can only be extremely deleterious to patient care.

Quite apart from the general issue the mother in this case may well have an excellent basis for a successful legal action for breach of confidence. Actions arising from breach of confidence are detailed time and time again in the annual reports of our defence societies, ' and with behaviour such as that detailed in this example it is no wonder that our subscription rates leap up year after year.

Michael BeECH

London SE24 9QY

1 Medical Defence Union. Annual report 1985. London: Medical Defence Union, 1985:71-3.

\section{Points}

\section{A false phoenix}

Dr David Waxman, (British Society of Medical and Dental Hypnosis, London W1) writes: You are correct in castigating those protagonists of that which you variously refer to as fringe or alternative medicine (21-28 December, p 1744). Unfortunately, hypnosis has been lumped together with those other approaches as a serious competitor of orthodox medicine. Hypnotherapy is used by doctors and dentists (surely "adequately trained" to make a diagnosis) who are usually also trained by the British Society of Medical and Dental Hypnosis. They are encouraged to qualify for a certificate of accreditation on reaching the required degree of competence and knowledge. Psychologists are trained to an equally high standard by the British Society of Experimental and Clinical Hypnosis. Hypnosis is not fringe or alternative medicine but is an additional or complementary form of treatment used for a number of well defined clinical conditions.

\section{What is "serum albumin"?}

Dr I B Holbrook (Department of Chemical Pathology, Hope Hospital, Salford M6 8HD) writes: Drs P G Hill and J S Harrop (4 January, p 61) comment on the problem of measuring human albumin by the bromocresol green dye binding method. I am well aware of this problem and, while most albumin measurements made at this hospital are performed using bromocresol green methods, low values $(<35 \mathrm{~g} / \mathrm{l})$ found in patients undergoing nutritional assessment for Professor Irving are reanalysed using an immunoturbidometric method and the results from this analysis are used. ${ }^{1}$ This method is highly specific and suffers from fewer problems than the dye binding methods currently in use. ${ }^{2}$

1 Pettit SH, Holbrook IB, Irving MH. Comparison of clinical scores and acute phase proteins in the assessment of acute Crohn's disease. $B r \mathcal{F}$ Surg 1985;72:1013-6.

2 Hill PG. The measurement of albumin in serum and plasma. Ann Clin Biochem 1985;22:565-78.

\section{Learned pain behaviour}

Dr R M EluIS and others (Wessex Regional Rehabilitation Unit, Odstock Hospital, Salisbury SP2 8BJ) write: As Dr S P Tyrer (4 January, p 1) points out, to recognise pain behaviour is one thing, to eradicate it is another. Even with a six week inpatient programme of behaviour modification in our rehabilitation unit, we improved the quality of life for only seven of 14 patients and returned only one of eight candidates to patients and returned only one of eight candidates to
full time work. Excessive drug consumption was, however, abolished in six of seven cases. May we reinforce Dr Tyrer's point that behaviour is a natural consequence of pain and does not imply a non-organic source of pain. Eight of our patients with spinal pain had had surgery for demonstrated lesions and one patient had multiple sclerosis. Leavitt et al have shown that the inability of an orthopaedic surgeon or physician to state the cause of low back pain does not imply any abnormal psychology. Pari passu an organic pain is quite capable of causing psychological "deterioration."2

1 Leavitt F, Garron DC, D'Angelo CM, McNeill TW. Low back pain in patient with and without demonstrable organic disease. Pain 1979;6:191-200.

2 Sternbach RA, Timmermans G. Personality changes associated with reduction in pain. Pain 1975;1:177-81.

Dr Anthony Ryle (St Thomas's Hospital, London SE1) writes: The important leading article by $\operatorname{Dr} S \mathrm{P}$ Tyrer (4 January, p 1) contains two omissions. Firstly, he fails to mention the role of doctors as "reinforcers." The patient who has been subjected to numerous investigations, a sequence of pharmacological treatments, electroconvulsive therapy, and perhaps surgery, with no sustained relief, will not easily be persuaded that his problem is psychological. Secondly, in concentrating on the behaviourist notion of reinforcement, Dr Tyrer pays no attention to the patient's initial "choice" and continuing need for the symptom. Here, an understanding of intrapersonal and interpersonal factors, such as that to be found in object-relations theory, for example, is required. Patients may not simply need our care and attention but also need us to disappoint or, at worst, harm them, and we must be aware of how our own anxious, omnipotent, or, at times, sadistic responses may be elicited by such patients. For many patients elucidating the meaning of their pain must accompany or precede the modification of the responses of others, and motivation for change will only be found when these meanings have been worked out.

\section{Resuscitation}

Lt Col I R Haywood (Royal Army Medical College, London SWIP 4RJ) writes: Every year about 80 newly registered doctors enter service in the army and their undergraduate origins are as numerous as the medical schools in the United Kingdom. A survey of a recent intake showed that the recently introduced improvements to the undergraduate curriculum do appear to be working. Some $96 \%$ of newly registered doctors have practised adult intubation and nearly $100 \%$ external cardiac massage, though a few admitted they had never been taught these procedures and must, therefore, have had to learn them the hard way when faced with an emergency. Only a few have had experience in intubating children. These figures represent a considerable improvement on those two and a half years ago, when only $20 \%$ of the doctors qualified for less than five years had ever passed an endotracheal tube on an adult. We therefore introduced trauma life support courses for all new medical officers. Discussion with these students does not, however, confirm the lack of interest suggested by $\mathrm{Dr}$ Paton. Likewise we have had many requests to extend this training to those already serving in both active and reserve forces....

\section{Pilonidal sinus of nipple in a canine beautician}

P W Bowers (Royal Cornwall Hospital, Truro, Cornwall) writes: I was interested to see the article by Dr Arpan Baneriee (21-28 December, p 1787). He suggests that this is a previously unrecorded site for this condition, but I reported three cases in $1982 .^{\prime}$ One was in a roustabout working in a sheep shearing gang and two were in hairdressers. Their problems were cleared by wearing suitable protective clothing.

1 Bowers PW. Roustabouts' and barbers' breasts. Clin Exp Dermatol 1982; 7:445-8.

\section{Correction}

\section{Medicine and South Africa}

We regret that the name of Sir John Stallworthy was mistakenly left off this letter by Mr Martin Birnstingl and 19 others (25 January, p 273). 